Vol. 24, No. 3, Juli 2021, hlm. 436-446

p-ISSN: 1410-9344; e-ISSN: 2549-5631

WARTA LPM

homepage: http://journals.ums.ac.id/index.php/warta

\title{
Penguatan Jurnalistik Berbasis Gender untuk Kader Pimpinan Cabang Ikatan Mahasiswa Muhammadyah AR Fakhruddin
}

\author{
Muria Endah Sokowati \\ Universitas Muhammadiyah Yogyakarta \\ email: muriaendah@umy.ac.id
}

\section{Article Info}

Submitted: 28 October 2020

Revised: 9 March 2021

Accepted: 12 April 2021

Published: 20 July 2021

Keywords: Journalism, Gender Ideology, Gender Equality, Gender Justice
Kata kunci: Jurnalistik, Ideologi Gender, Kesetaraan Gender, Keadilan Gender

\begin{abstract}
The understanding of gender among adolescents is very low. Many cases motivated by the weak a wareness of male and female youth about gender ideology are often cited as the source of the problem. For example, cases of sexual violence, sexual harassment both physically, psychologically, and symbolically, are widely disclosed and published through the media, showing the low understanding of adolescents on gender awareness and justice. Based on this experience, we as academics, with background in media and communication studies and have concern about youth and gender issues, feel responsible for providing solutions to these problems. We started from the micro level, in the environment closest to us as lecturers at Universitas Muhammadiyah Yogyakarta. Partnering with PC IMM AR Fakhruddin, we propose a Gender Literacy activity for Students, called as gender-based journalism training for PC Cadres IMM AR Fakhruddin. This activity is an educational activity that focuses on planting concepts and theories about gender justice and equality. With these concepts and theories, we direct the participants to write personal experiences related to gender problems into journalistic work products. We provide assistance on the writing, until it becomes a published book, containing eight articles written by the participants. The book, as a reflective documentation of the student's gender understanding, will also be able to become a means of building gender awareness for other people. Participants in this activity are not only open to their insights and experiences about gender ideology, but also able to become agents of gender socialization for the surrounding environment.
\end{abstract}
Abstrak
Pemahaman tentang gender di kalangan remaja sangat rendah. Banyak kasus-kasus yang dilatarbelakangi oleh lemahnya kesadaran remaja laki-laki dan perempuan tentang ideologi gender kerap disebut sebagai sumber permasalahan. Sebut saja kasus kekerasan seksual, pelecehan seksual baik secara fisik, psikologis, maupun simbolis banyak diungkap dan dipublikasikan lewat media menunjukkan rendahnya pemahaman 
remaja atas kesadaran dan keadilan gender. Dilatarbelakangi oleh hal tersebut, maka kami sebagai akademisi yang memiliki latar-belakang kajian media dan komunikasi yang menaruh perhatian terhadap persoalan remaja dan gender merasa turut bertanggung-jawab untuk memberikan solusi atas persoalan tersebut. Kami memulainya dari level mikro, yaitu di lingkungan yang terdekat dengan kami selaku dosen Universitas Muhammadiyah Yogyakarta. Bermitra dengan PC IMM AR Fakhruddin, kami mengajukan kegiatan literasi gender untuk mahasiswa, yaitu pelatihan jurnalistik berbasis gender untuk kader PC IMM AR Fakhruddin. Kegiatan tersebut merupakan edukasi yang memfokuskan pada penanaman konsep dan teori tentang keadilan dan kesetaraan gender. Berbekal konsep dan teori tersebut, selanjutnya peserta kami arahkan untuk menuliskan pengalaman-pengalaman personal yang berhubungan dengan problem gender ke dalam produk karya jurnalistik. Kami melakukan pendampingan pada penulisan tersebut, hingga menjadi sebuah buku yang telah dipublikasikan, berisi delapan tulisan hasil karya peserta. Buku tersebut, selain menjadi dokumentasi reflektif pemahaman gender mereka, mampu menjadi sarana untuk membangun kesadaran gender bagi pihak lain. Peserta kegiatan ini tidak hanya terbuka wawasan dan pengalamannya tentang ideologi gender, namun juga mampu menjadi agen sosialisasi gender bagi lingkungan sekitarnya.

\section{PENDAHULUAN}

\section{Analisis Situasi}

Kegiatan pelatihan jurnalistik berbasis gender ditujukan kepada mahasiswa yang tergabung dalam PC IMM AR Fakhruddin. Sekretariat PC IMM AR Fakhruddin berlokasi di jalan Sultan Agung nomor 14, Wirogunan, Pakualaman, Kota Yogyakarta. Kegiatan ini dilakukan berpegang pada pemikiran pentingnya remaja memiliki kesadaran atas kesetaraan gender. Upaya yang perlu dilakukan adalah dengan membangun kesadaran kritis di kalangan remaja tentang problem gender yang terjadi di sekitar mereka. Salah satu sarana yang paling realistis saat ini adalah dengan mendorong kemampuan menulis mereka dalam mengekspresikan gagasan tentang persoalan gender. Pelatihan jurnalistik dapat menjadi wahana mengeskpresikan gagasan.

Dewasa ini, isu-isu kesetaraan gender sudah mulai diterima dan merubah gagasan tentang gender di masyarakat. Pada tahun 2013, sebuah lembaga pemerhati perilaku konsumen yang berbasis di Los Angeles, The Intelligence Group, merilis sebuah penelitian yang menunjukkan bahwa sekitar dua per tiga generasi milenial mempercayai bahwa saat ini persoalan gender semakin kabur dan tidak lagi berlaku sebagaimana generasi terdahulu memandang serta menerapkannya dalam kehidupan seharihari. Dalam survei tersebut dituliskan bahwa kaum muda memahami gender berdasarkan pemahaman individual mereka masing-masing, dan bukan mengikuti peran gender secara tradisional (Hasan, 2017).

Fakta tersebut membuat pihak-pihak yang paham dan peduli kesetaraan gender merasa optimis dengan para generasi muda. Meskipun demikian, pemahaman tersebut tidak diikuti oleh perilaku yang toleran terhadap perbedaan berbasis gender. Kasus kekerasan seksual mulai dari verbal, psikis hingga fisik masih banyak terjadi di kalangan remaja. Sebut saja kasus pelecehan seksual, kehamilan pramarital, perkosaan, dan atau bullying yang di mana remaja menjadi pelaku dan korban marak diberitakan di media.

Mengutip tulisan Boediarsih, dkk (dalam Boediarsih, Shaluhiyah, 2016) menyatakan bahwa bentuk diskriminasi gender telah tampak pada masa remaja. Dalam hal ini, perempuan 
adalah pihak yang sering menjadi korban kekerasan dalam berpacaran. Berdasarkan data LRC-KJHAM Jawa Tengah, antara bulan November 2012 hingga Juni 2013 telah terjadi 301 kasus kekerasan terhadap perempuan. Bentuk kekerasan yang dialami yaitu: 265 kasus kekerasan seksual, 100 kasus kekerasan fisik, dan 60 kasus kekerasan psikis. Lebih lanjut data tersebut menjelaskan bahwa kekerasan seksual pada umumnya dialami oleh kelompok umur remaja.

Kekerasan seksual yang umumnya terjadi pada remaja dipicu oleh banyak faktor, salah satunya adalah kurangnya pengetahuan remaja tentang pendidikan ideologi gender. Informasi dan pengetahuan inilah yang menjadi dasar persepsi seorang remaja tentang seksualitas. Misalnya menurut Dude dan Kau Fag (dalam Cole, 2015), di kalangan remaja, anak laki-laki mengadopsi dan melakukan praktik dominasi, agresif, mengendalikan, dan maskulin secara seksual. Pemahaman tentang gender yang tidak tepat ini sesungguhnya adalah problem kultural yang berlangsung dari satu generasi ke generasi sehingga dianggap sebagai sesuatu yang alamiah. Pemahaman tentang gender yang timpang ini akhirnya diterima sebagai hal yang normal tanpa pernah dipertanyakan.

Tentu saja hal tersebut menjadi keprihatinan kami sebagai akademisi yang sudah semestinya memiliki tanggung jawab untuk turut memberikan perubahan progresif pada generasi muda. Untuk itu pemahaman kritis generasi muda tentang ideologi gender menjadi hal yang mutlak. Kami berprinsip bahwa anak muda sudah seharusnya tidak lagi sekadar sadar tentang kesetaraan gender, namun bisa menjadi pelaku aktif sosialisasi kesetaraan gender sehingga dapat menciptakan perubahan. Atas dasar niat baik itulah, kegiatan Pengabdian Kemitraan Masyarakat (PKM) ini kami laksanakan.

Kegiatan yang kami lakukan tidak berdasarkan pada kasus khusus yang terjadi di lembaga mitra, dalam hal ini adalah PC IMM AR Fakhruddin. Sangat susah untuk mencari data tentang problem gender di lokasi-lokasi tertentu, karena sebagian besar problem gender adalah problem yang tidak mudah ditemukan. Sebut saja kasus kekerasan dalam berpacaran yang didefinisikan sebagai perilaku atau tindakan seseorang dalam percintaan (pacaran) yang terjadi bila salah satu pihak merasa terpaksa, tersinggung, dan disakiti dengan apa yang telah dilakukan pasangannya. Kasus tersebut akan sangat susah untuk didata, bisa jadi karena dianggap hal yang wajar dalam masa pacaran terjadi masalah-masalah seperti itu padahal kasus kekerasan dalam pacaran seringkali menimbulkan trauma berkepanjangan; atau tidak ada laporan atas kasus-kasus kekerasan dalam pacaran karena pihak perempuan sebagai korban seringkali justru dipersalahkan.

Alasan-alasan itulah yang menyebabkan kami tidak melampirkan data konkrit kasus yang terjadi di kalangan mahasiswa di lembaga pendidikan atau kota tertentu. Kami tetap meyakini bahwa problem gender adalah problem serius di kalangan generasi muda, sehingga kegiatan yang bersifat menanamkan kesadaran gender di kalangan remaja adalah sesuatu yang mendesak untuk dilakukan. Lalu mengapa kegiatan ini dilakukan dengan target mahasiswa yang tergabung dalam PC IMM AR Fakhruddin? Alasan yang mendasarinya adalah karena PC IMM AR Fakhruddin kami nilai sebagai lembaga yang sudah siap menjalankan kegiatan ini. kader IMM siap untuk menerima dan mengimplementasikan gagasan tentang gender equality atau kesetaraan gender. Kader IMM UMY mempunyai trilogi kemasyarakatan, artinya ketika kader PC IMM AR Fakhruddin memiliki perhatian dan keprihatinan yang sejalan dengan kami. Adanya kesamaan gagasan, mendorong kader-kader PC IMM AR Fakhruddin lebih mudah menerima dan memahami materi tentang konsep dan ideologi gender yang akan kami sampaikan. Ke depannya, kami menargetkan bahwa kader-kader PC IMM AR Fakhruddin dapat menerapkan prinsip-prinsip kesetaran dan keadilan gender dalam kehidupan sehari-hari.

Selainitu, Ikatan Mahasiswa Muhammadiyah juga memiliki tiga kompetisi dasar, salah satunya adalah intelektualitas. Hal tersebut juga menjadi alasan pendorong bagi kami untuk memilih PC IMM AR Fakhruddin sebagai target kegiatan ini, karena kader PC IMM AR Fakhruddin harus terus meningkatkan kualitas keilmuannya dan pemahaman kritisnya atas isu-isu gender. Faktor 
lain adalah humanitas, di mana prinsip ini mendorong kader-kader PC IMM AR Fakhruddin untuk mengimplementasikan wawasannya kepada masyarakat luas. Tentu saja hal ini sejalan dengan visi kegiatan ini, yang mendorong peserta menjadi agen sosialisasi prinsip-prinsip kesetaraan dan keadilan gender di dalam kehidupan sosial. Kegiatan ini kami harapkan dapat menjadi pilot project.

\section{Permasalahan Mitra}

Berdasarkan analisis situasi yang telah dipaparkan di atas, maka apa yang kami uraikan pada bagian ini bukanlah permasalahan yang dialami oleh mahasiswa yang tergabung dalam PC IMM AR Fakhruddin, namun justru pada kesiapan dan komitmen PC IMM AR Fakhruddin untuk mendukung kegiatan ini. Bentuk kesiapan dan komitmen PC IMM AR Fakhruddin adalah sebagai berikut:

a. PC IMM AR Fakhruddin memiliki kepedulian tinggi pada permasalahan sosial. Bentuk kepedulian tersebut dituangkan dalam beberapa kegiatan seperti live in di Kampung Jlagran, diskusi-diskusi rutin mengenai Hak Asasi Manusia, Sekolah Tiga Menit, Sekolah Rakyat, dan diskusi publik mengenai urgensi RUU P-KS. Adanya kepedulian pada problem dan isu sosial, diikuti tradisi kegiatankegiatan konkrit untuk memberikan jalan keluar bagi problem-problem tersebut menjadi hal yang penting bagi terlaksananya program ini.

b. PC IMM AR Fakhruddin memiliki kaderkader yang mumpuni, dilihat dari kaderkader PC IMM AR Fakhruddin kerap memenangkan berbagai kompetisi baik tingkat kampus hingga tingkat nasional. Selain itu, kampus UMY sendiri juga memiliki sarana dan prasarana yang sangat memadai untuk melaksanakan kegiatan yang kami ajukan.

Foto-foto berikut adalah ilustrasi kegiatankegiatan progresif yang telah dilakukan oleh kader-kader PC IMM AR Fakhruddin yang menunjukkan kepedulian mereka atas persoalan-persoalan sosial.

Untuk itu, kami selaku tim program Literasi Gender PKM UMY, sebagai inisiator kegiatan memfasilitasi tim pelatih, modul kegiatan dan bahan/materi kegiatan (audio visual dan tulisan). Sementara pihak mitra, yaitu PC IMM AR Fakhruddin menyediakan peserta. Target kegiatan ini adalah publikasi karya tulis jurnalistik peserta dalam bentuk buku.

\section{Tinjauan Pustaka}

Problem ketidaksetaraan gender dan seksualitas menjadi bagian dari kehidupan
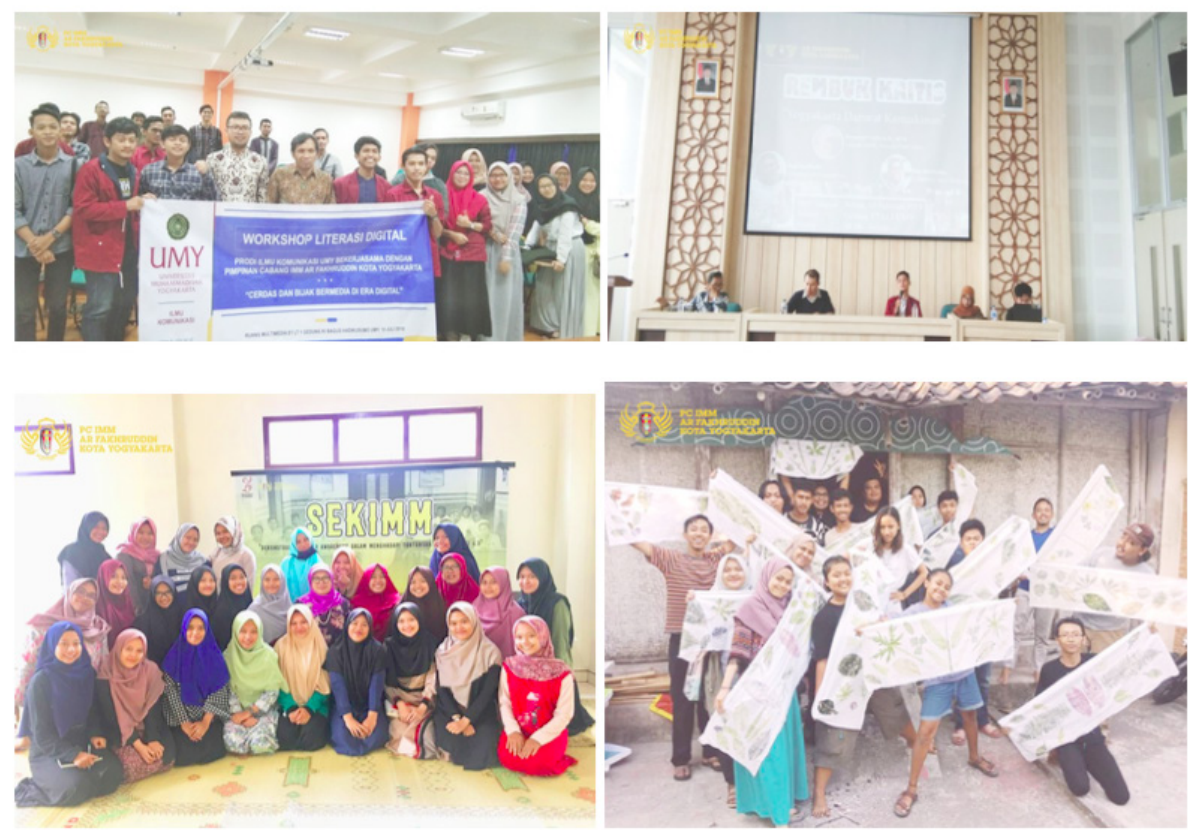

Gambar 1. Kegiatan-Kegiatan yang Dilakukan oleh PC IMM AR. Fakhruddin 
sehari-hari. Masalah kekerasan seksual misalnya, menjadi sesuatu yang sering kita dengar dan saksikan. Masalah tersebut kerap menempatkan perempuansebagaikorban.Menurutlaporan PBB tahun 2018 misalnya hampir 35\% perempuan di dunia pernah mengalami kekerasan fisik dan seksual. Misalnya saja di Bangladesh sebanyak 84\% dan di Vietnam sejumlah $87 \%$ perempuan mengalami penghinaan dan pelecehan seksual. Sementara di Tanzania lebih dari 50\% kekerasan seksual dilakukan oleh suami atau pasangannya, bahkan di Ethiopia angkanya lebih dari 50\%. Di Nigeria, 43\% perempuan terpaksa menjalani pernikahan dini, dan di Afrika Selatan 150 perempuan diperkosa setiap hari (Witriani dan Kusuma, 2019).

Data lain menyebutkan, kekerasan seksual di ranah rumah tangga menempati ranking kedua terbesar, yaitu sebanyak 3.495 kasus atau 34\% setelah kekerasa fisik. Perkosaan menempati posisi tertinggi sebanyak 1.389 kasus, pencabulan sebanyak 1.266 kasus, dan perkosaan dalam perkawinan sebanyak 135 kasus. Pelaku kekerasan tertinggi adalah pacar, yaitu sebesar 2.017 orang. Sementara itu, di ranah komunitas, kekerasan seksual menempati urutan tertinggi hingga mencapai 2.290 kasus atau $74 \%$ dari total keseluruhan kasus yang berjumlah 3.092. Sama halnya kekerasan seksual di ranah rumah tangga, perkosaan di ranah ini juga menjadi kasus terbanyak hingga mencapai 1.036 kasus, diikuti pencabulan sebanyak 838 kasus. Sebagian besar korban adalah di usia muda, yaitu rentang usia 13 hingga 40 tahun (Rofi'ah dan Jasminto, 2018).

Anak-anak dan remaja memang kerap menjadi objek kasus kekerasan seksual. Data dari KPAI tahun 2017 (dalam Sujadmi, Febriani, L., 2018) menyebutkan bahwa peningkatan kasus pelecehan seksual terhadap anak dan remaja dari tahun ke tahun mengalami peningkatan hingga mencapai 100\%. Efek dari kekerasan seksual pada anak dan remaja cukup mengerikan, sebut saja depresi, gangguan stres pascatrauma, kegelisahan, kecenderungan untuk menjadi korban lebih lanjut saat dewasa, cedera fisik dan sebagainya (Bahransyaf, 2016). Problem lain yang juga menjadikan anak-anak dan remaja sebagai korban adalah kasus pernikahan dini yang semakin marak. Pernikahan dini sebagai bagian dari kultur, domestifikasi perempuan, atau solusi atas problem ekonomi perempuan menempatkan perempuan dalam kondisi yang tidak menguntungkan. Perceraian adalah kasus yang sering terjadi (Puspita, Dharma, dan Isna, 2019).

Bukan hanya soal kekerasan seksual sebagai implementasi dari problem ketidakadilan gender. Banyak tindakan yang dilakukan baik oleh laki-laki maupun perempuan dalam kehidupan sehari-hari yang mencerminkan hal tersebut. Gagasan bahwa laki-laki adalah pencari nafkah, perempuan adalah pengasuh anak, laki-laki adalah pemimpin, perempuan adalah jenis kelamin kedua setelah laki-laki, adalah sesuatu yang diterima secara taken for granted tanpa pernah dipertanyakan. Gagasan yang bersumber dari budaya patriarki tersebut lagi-lagi menempatkan perempuan dalam posisi yang kurang menguntungkan dengan segala stigma dan stereotipe. Sebut saja, perempuan itu aseksual, sehingga saat perempuan menunjukkan hasratnya makan dilabeli sebagai perempuan jalang. Contoh lainnya adalah perempuan adalah makhluk feminin, akibatnya saat perempuan memiliki karakter maskulin akan dianggap perempuan yang melampaui kodratnya.

Prasangka dan stereotipe terhadap perempuan berasal dari banyak sumber (Nelson dalam Ashuro, Siregar, dan Rochani, 2010). Teori pembelajaran sosial menjelaskan bahwa sejak usia dini, anak-anak diajarkan oleh lingkungan termasuk keluarga bagaimana menjadi laki-laki dan perempuan. Anak laki-laki akan diajarkan nilai-nilai tentang maskulinitas, seperti agresivitas, ketangkasan, keberanian, dan sejenisnya. Sementara perempuan lebih dididik untuk menjadi feminin. Hal tersebut dilakukan secara turun temurun dan dinormalisasi sehingga dipahami menjadi sebuah kewajaran.

Akibatnya, seseorang akan memahami bagaimana peran gender sesuai dengan yang diajarkan oleh lingkungan terdekatnya. Hasil penelitian terhadap siswa SMA menunjukkan bahwa $56.4 \%$ siswa laki-laki dan $84.9 \%$ perempuan mengatakan ibu adalah tokoh yang mengajari cara berperilaku sesuai dengan gender (Warmiyati, Wijayanti, Darmoyo, 2018) mengingat ibu dalam tradisi masyarakat patriarkis adalah sosok yang paling dekat 
dengan anak karena ia dilekati tanggung jawab atas pengasuhan anak. Saat anak-anak beranjak dewasa, sosialisasi tentang gender digantikan oleh lingkungan yang lebih luas, media massa misalnya.

Remaja memiliki media habit yang cukup tinggi. Penelitian menunjukkan bahwa remaja usia 8-18 tahun menghabiskan waktu hampir 8,5 jam dalam sehari untuk mengkonsumsi media. Mulai usia 8 tahun, remaja meluangkan waktunya sekitar 4,5 jam untuk menatap layar media, seperti TV, DVD, atau film, sementara sisanya untuk mengkonsumsi media audio, media cetak, video games, dan komputer (Kirsch, 2010:13). Berdasarkan data tersebut, maka media menjadi salah satu sarana dalam proses identifikasi peran, performance, dan identitas kelas-kelas dalam masyarakat, baik itu berdasarkan gender, etnis maupun usia. Media memperkuat konstruksi identitas dan peran yang disosialisasikan oleh orang tua dan guru. Misalnya, laki-laki maskulin adalah laki-laki heteroseksual. Media menekankan role model dan hal-hal yang tabu bagi laki-laki. Role model tersebut adalah laki-laki heteroseksual dan hal tersebut mendorong para remaja untuk menjadi demikian. Media tak hanya menjadi sarana sosialisasi tentang peran gender bagi remaja, namun juga untuk menguji peran gender yang telah mereka pelajari sebelumnya lewat orang tua (Kusuma, 2017).

Untuk itulah pembelajaran berperspektif gender menjadi solusi dari permasalahan ini. Pembelajaran berperspektif gender adalah sebuah proses pendidikan yang dijiwai oleh kesadaran adanya kesetaraan gender (Purwahida dan Huda, 2010). Pendidikan berperspektif gender bisa menjadi alternatif di antara sosialisasi yang ada selama ini yang merepresentasikan kultur yang patriarkis. Mahasiswa menjadi pilihan yang tepat dari pembelajaran ini, karena mahasiswa merupakan agen perubahan. Mahasiswa yang menjadi sasaran pembelajaran diharapkan mampu menjadi agen sosialisasi kesetaraan gender pada kalangan-kalangan lainnya. PCC IMM AR Fakhruddin menjadi pilihan target program ini dengan mempertimbangakan alasan-alasan yang telah dijelaskan di bagian sebelumnya.

\section{Solusi Permasalahan}

Problem ketimpangan gender yang dialami oleh remaja pada umumnya, dapat diatasi dengan peningkatan kesadaran gender. Untuk itu, kegiatan yang kami lakukan adalah pelatihan jurnalistik berbasis gender kepada para kader PC IMM AR Fakhruddin. Tujuan dari kegiatan ini adalah melatih kepekaan peserta terhadap persoalan-persoalan gender sehingga mampu membangun kesadaran gender mereka.

Deskripsi dari kegiatan yang kami kerjakan adalah sebagai berikut:

a. Kegiatan ini berjudul "Pelatihan Jurnalistik Berbasis Gender untuk Mahasiswa". Kegiatan ini diikuti oleh kader PC IMM AR Fakhruddin. Peserta berjumlah 10 orang, sesuai dengan target peserta (15-20 peserta) dengan frekuensi 4 kali pertemuan. Kegiatan ini dilaksanakan satu minggu satu kali dengan durasi 120 menit. Selama pertemuan tersebut, peserta diasah kepekaan gendernya dalam bentuk diskusi dan studi kasus. Peserta juga diberi pelatihan menulis sebagai wahana ekspresi kesadaran gender yang telah mereka peroleh. Karya tulis mereka akan dipublikasikan dalam bentuk buku yang diterbitkan.

b. Luaran kegiatan ini adalah buku yang mendokumentasikan karya tulis peserta. Dari 10 peserta, kami berhasil mengumpulkan 8 tulisan.

\section{Tujuan Program}

Program ini memiliki beberapa tujuan sebagai berikut:

1. Membangun kesadaran mahasiswa, dalam hal ini adalah kader PC IMM AR Fakhruddin, tentang kesetaraan gender dan problemproblem gender yang terjadi.

2. Melatih kepekaan mahasiswa, dalam hal ini kader PC IMM AR Fakhruddin terhadap problem gender

3. Menjadi agen sosialisasi pendidikan kesetaraan gender lewat tulisan-tulisan yang akan dipublikasikan.

\section{Manfaat Program}

Lewat program literasi gender, mahasisiwa dalam hal ini kader PC IMM AR Fakhruddin dapat 
meningkatkan pengetahuan dan wawasannya tentang gender dan seksualitas, dan menambah pengalaman mereka di bidang jurnalistik dan penulisan artikel.

\section{METODE}

Metode pelaksanaan kegiatan ini dapat dilihat pada diagram alir beserta penjelasannya (gambar 2).

a. Workshop Pemahaman Kesadaran dan Kesetaraan Gender

Kegiatan ini dilakukan dengan tujuan membangun pemahaman peserta pelatihan tentang ideologi gender yang akan membantu mereka memahami kesadaran dan kesetaraan gender. Workshop dilakukan lewat metode diskusi dengan memberikan materi dan konsep dasar, studi kasus dan pemecahan masalah. Kegiatan ini dilakukan selama dua kali, yaitu tanggal 8 dan 15 Maret 2020, masing-masing pertemuan berdurasi 120 menit (Pukul 10.00-12.00

\section{Metode Kegiatan Literasi Gender}

Workshop Pemahaman Kesadaran dan Kesetaraan Gender

Sesi 1: Membengkar Ideologi Gender oleh Dr. Muria Endah Sokowati Sesi 2: Ketidakadilah Gender oleh Dr. Muria Endah Sokowati

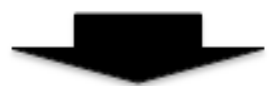

Pelatihan Penulisan Karya Jurnalistik

Sesi 1: Penulisan Feature Isu-Isu Gender dan Seksualitas oleh Dr. Faiar Junaedi Sesi 2: Praktik Menulis oleh Dr. Eaiar Junaedi

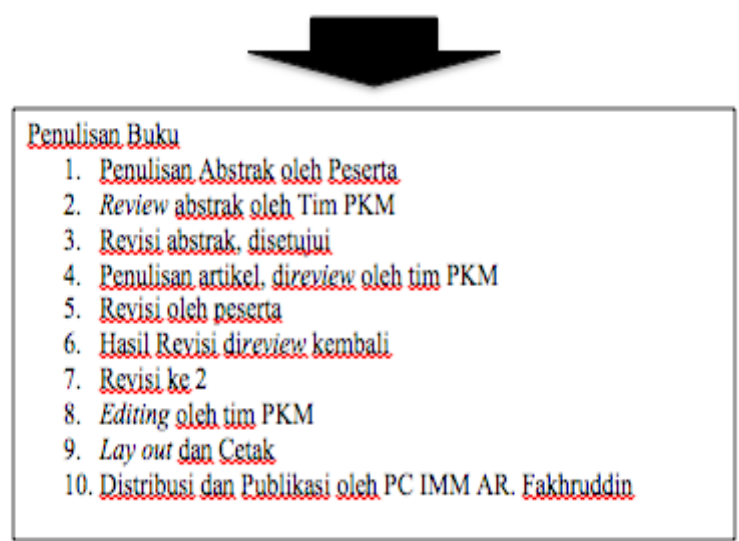

Gambar 2. Diagram Metode Kegiatan Literasi Gender
WIB). Pengisi materi ini adalah yaitu Dr. Muria Endah Sokowati). Materi yang diberikan adalah "Membongkar Ideologi Gender" dan "Ketidakadilan Gender".

b. Pelatihan Penulisan Karya Jurnalistik

Kegiatan berikutnya adalah pelatihan menulis atau produksi karya jurnalistik. Peserta akan dilatih teknik-teknik penulisan jurnalistik. Materi yang diberikan adalah pemahaman tentang dasar-dasar jurnalistik dan teknik penulisan. Kegiatan ini direncanakan dilakukan selama dua kali pertemuan. Namun akibat pendemi Covid-19, kegiatan ini terlaksana secara asynchronous. Pengisi sesi ini, yaitu Dr. Fajar Junaedi mengirimkan materi pembelajaran yang berjudul "Penulisan Feature Isu-Isu Gender dan Seksualitas" secara online. Selanjutnya peserta melakukan diskusi dengan pemateri secara personal melalui Whatsapp.

\section{c. Penulisan Buku}

Dalam kegiatan ini, peserta sudah mulai praktik menulis. Peserta diminta untuk mengirimkan abstrak. Setelah abstrak terkumpul, tim PKM melakukan proses review. Hasil review diserahkan pada peserta, diikuti dengan penulisan artikel sebanyak 2500 kata. Selama proses penulisan tim PKM melakukan proses review sebanyak dua kali. Setelah peserta melakukan revisi, tim PKM melakukan proses penyuntingan, dan dilanjutkan proses cetak buku. Buku diserahkan pada PC IMM AR Fakhruddin untuk didistribusikan.

\section{HASIL DAN PEMBAHASAN}

\section{Kegiatan Workshop}

Program ini diawali dengan kegiatan Workshop Pemahaman Kesadaran dan Kesetaraan Gender. Kegiatan ini diikuti oleh 10 peserta. Pengisi kegiatan ini adalah Dr. Muria Endah Sokowati. Di minggu pertama, materi disampaikan adalah "Membongkar Ideologi Gender". Kegiatan dibuka dengan melakukan brainstorming tentang konsep gender untuk memperoleh gambaran pemahaman gender peserta. Selanjutnya adalah penyampaian materi yang diikuti oleh diskusi dan tanya jawab. 
Pemahaman gender di kalangan masyarakat masih problematis. Banyak sekali problem yang terjadi dalam kehidupan seharihari dilatarbelakangi oleh masalah ideologi gender. Adanya narasi besar tentang gender yang diyakini sebagai sesuatu yang mutlak menjadi akar persoalannya. Narasi besar tersebut dipahami secara taken for granted (tanpa pernah dipertanyakan), dan dipercaya sebagai satu-satunya gagasan yang benar. Adanya pemahaman ini menyebabkan gagasan gender lainnya sebagai pemahaman yang sesat. Di sesi pertama ini, peserta perlu menguasai konsep tentang ideologi gender. Ideologi gender merupakan gagasan, ide dan pemahaman individu tentang gender yang diyakini dan diimplementasikan dalam kehidupan seharihari. Ideologi gender membangun konstruksi tentang peran, fungsi, sifat berdasarkan kategori gender yang seringkali bias. Untuk itu peserta perlu dijelaskan tentang konsep dasar tentang seks, gender, dan seksualitas. Pada pemaparan ini peserta diharapkan tidak hanya memahami di tataran kognisi dan pengetahuan. Namun, peserta diharapkan memiliki kesadaran kritis dan kepekaan terhadap persoalan-persoalan yang berbasis ideologi gender.

Peserta terlihat antusias untuk mendiskusikan tentang konsep dan pengalaman terkait dengan problem gender. Dokumentasi kegiatan di hari pertama tersebut dapat dilihat pada gambar 3 .

Pada minggu kedua yang berlangsung satu minggu kemudian, peserta memperoleh materi tentang "Ketidakadilan Gender". Kali ini kegiatan adalah diskusi, pemateri menyampaikan beberapa kasus tentang ketidakadilan gender yang langsung ditanggapi oleh peserta. Materi yang disampaikan pada sesi kali ini meliputi: Bentuk-Bentuk Ketidakadilan Gender, Rape Culture atau Budaya Perkosaan, Pelecehan Seksual, dan Ketidakadilan Gender di Media. Di sini peserta disajikan secara komprehensif
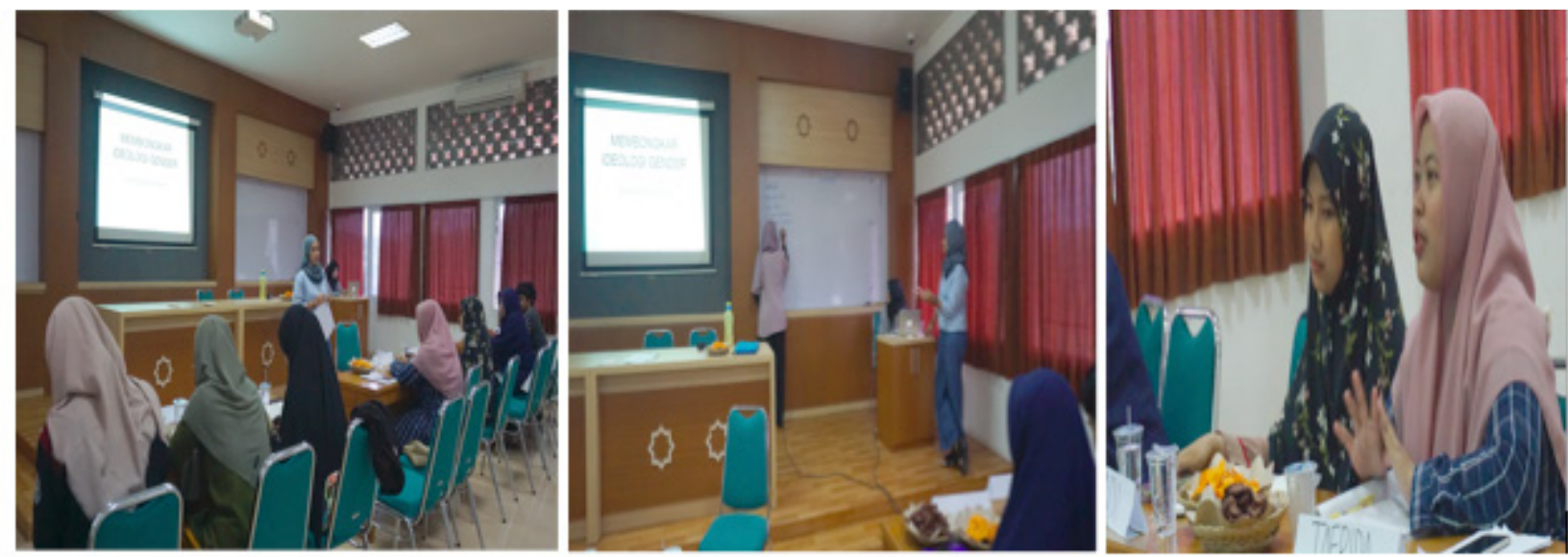

Gambar 3. Kegiatan Workshop Pemahaman dan Kesetaraan Gender Minggu Pertama
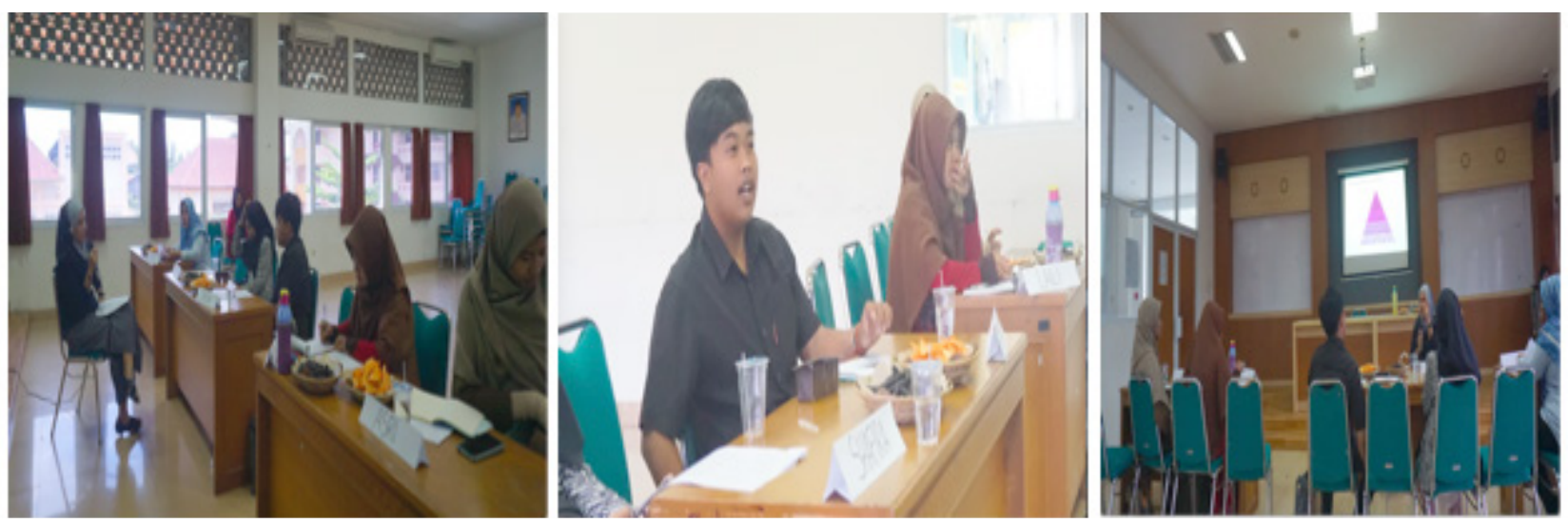

Gambar 4. Kegiatan Workshop Pemahaman dan Kesetaraan Gender Minggu Kedua 
kasus-kasus yang terjadi di masyarakat terkait dengan masalah ketidakadilan gender, juga bagaimana publikasi kasus-kasus tersebut di media yang kerap memperlakukan korban dengan tidak semestinya.

Banyak pertanyaan-pertanyaan yang diajukan oleh para peserta, misalnya mengapa media kerap memposisikan perempuan sebagai penyebab terjadinya kasus perkosaan terhadap dirinya; atau contoh lainnya adalah mengapa melihat laki-laki yang melakukan pelecehan terhadap perempuan dianggap sebagai perilaku yang wajar bahkan tampak jantan di mata masyarakat. Pertanyaan-pertanyaan tersebut kemudian didiskusikan sehingga peserta dapat benar-benar memahami materi yang diberikan. Jalannya diskusi dapat dilihat pada Gambar 4.

Workshop minggu ketiga dan keempat yang membahas tentang penulisan karya jurnalistik dengan pemateri Dr. Fajar Junaedi bertepatan denganawal masa pendemi Covid-19di Indonesia. Himbauan pemerintah untuk melakukan semua aktivitas di rumah menyebabkan workshop dengan materi Penulisan Feature Isu-Isu Gender dan Seksualitas dilakukan secara online. Akibat kondisi yang serba mendadak dan tidak pasti, tim literasi gender membuat keputusan untuk mengirimkan materi secara tertulis kepada seluruh peserta. Peserta diminta untuk mempelajari secara mandiri. Pemateri mempersilakan peserta untuk menanyakan secara langsung lewat Whatsapp kepada materi jika ada hal-hal yang perlu didiskusikan lebih lanjut.

Dr. Fajar Junaedi dalam materi yang berjudul Menulis Feature dalam Perspektif Jurnalisme Gender mengawalinya dengan fakta bahwa komposisi jurnalis perempuan di ruang redaksi lebih sedikit dibanding laki-laki, dan minimnya jurnalis perempuan yang menempati posisi stategis di pengambil kebijakan di media. Hal ini membuat banyak media tidak memiliki sensitivitas gender. Minimnya kesadaran gender di ruang redaksi juga menyebabkan pemuatan narasumber perempuan yang memiliki kemampuan dan kompetensi lebih baik, menjadi sangat terbatas. Pemberitaan terhadap isu politik, ekonomi hingga olahraga dan sejumlah isu yang terkait dengan perempuan misalnya, sangat bias gender. Ini lagi-lagi karena banyaknya pengelola ruang redaksi diisi jurnalis yang belum mempunyai pemahaman gender, sehingga perspektif yang muncul masih sangat maskulin. Untuk itu, penting untuk mengenalkan jurnalisme sensitif gender kepada mahasiswa. Tujuannya, mereka memiliki sensitifitas gender dalam penulisan jurnalistik yang bisa dimanfaatkan dalam penulisan di pers mahasiswa, blog maupun karier jurnalistik di masa depan.

Selanjutnya Junaedi memberikan panduan ringkas tentang bagaimana menulis feature dengan mengedepankan sensitivitas gender. Feature adalah jenis berita yang bisa dikategorikan sebagai berita ringan (soft news). Sebagaimana yang kita ketahui ada dua jenis berita yaitu berita keras (hard news) dan berita ringan (soft news). Kategori berita yang pertama menekankan pada kecepatan berita, dengan pola penulisan piramida terbalik. Piramida terbalik adalah struktur berita yang menempatkan bagian penting dari berita sebagai kepala berita atau lead. Bagian yang kalah penting ditempatkan di dalam tubuh berita. Kategori kedua adalah jenis berita yang tidak ditujukan untuk memberi informasi yang memiliki nilai kemanusiaan (human interest) sehingga tidak lekang oleh waktu untuk dibaca. Selanjutnya disampaikan teknis-teknis penulisan feature kepada para peserta yang kemudian langsung dipraktikkan oleh peserta dalam penulisan artikel-artikelnya.

\section{Penulisan Buku}

Setelah proses workshop selesai, peserta diminta untuk mengirimkan abstrak kepada tim literasi gender. Pada pertengahan bulan April 2020, ada delapan abstrak yang berhasil dikumpulkan. Setelah melalui proses review, abstrak dikembalikan pada peserta dan peserta diminta untuk membuat artikel panjang sejumlah 2500 kata. Satu bulan kemudian, peserta diminta untuk mengumpulkan artikel hasil karyanya. Setelah terkumpul, tim melakukan review kembali atas delapan artikel yang terkumpul. Hasil review dikembalikan pada peserta. Selanjutnya peserta diminta untuk melakukan revisi. Kali ini peserta membutuhkan waktu yang cukup lama untuk menyempurnakan tulisannya. Pada pertengahan bulan Agustus 2020 peserta mengumpulkan tulisannya. Berikutnya tim literasi gender melakukan proses penyuntingan. 


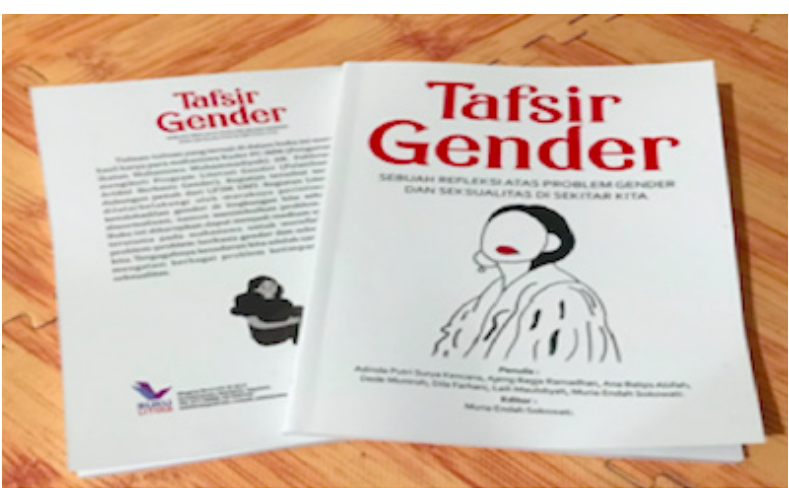

Gambar 5. Buku Kumpulan Tulisan Peserta Literasi Gender

Selanjutnya diserahkan ke percetakan. Buku dengan judul Tafsir Gender: Sebuah Refleksi Atas Problem Gender dan Seksualitas di Sekitar Kita berhasil diterbitkan dan dipublikasikan pada pertengahan bulan Oktober 2020.

Delapan judul artikel yang terangkum dalam buku Tafsir Gender adalah "Pentingnya Pendidikan Seks dan Gender untuk Mencegah Kekerasan Seksual”, "Perempuan pada Umumnya, Kok!", "Agama, Budaya dan Media Sebagai Cikal Bakal Ketidakadilan Gender terhadap Perempuan", "Refleksi Atas Lagu "Memang Kenapa Bila Aku Perempuan" Karya Melly Goeslaw", "Jangan Biarkan Internalized Mysogyny dalam Diri Kita, Saatnya Mendukung Sesama Perempuan", "Transpuan Juga Manusia”, "Ruang Aman Mengekspresikan Iman Para Transpuan", "RUU Ketahanan Keluarga: Pelecehan LakiLaki Oleh Negara", dan "Reynhard Sinaga dan Normalisasi Perkosaan". Buku dicetak sebanyak 100 eksemplar, dan diserahkan kepada PC IMM AR. Fakhrudin. Oleh PC IMM AR Fakhrudin, buku tersebut diberikan kepada anggota-anggota IMM, dan dipublikasikan lewat media sosial dan portal berita seperti yang didokumentasikan pada Gambar 6.

Terbitnya buku Tafsir Gender sebagai produk luaran dari Kegiatan Literasi Gender Bagi Mahasiswa menjadi akhir dari kegiatan Pengabdian pada Masyarakat yang kami inisiasi. Kegiatan ini akan terus kami selenggarakan di waktu-waktu ke depan sebagai bagian dari komitmen kami untuk melakukan edukasi tentang gender dan seksualitas

\section{SIMPULAN}

Kegiatan Literasi Gender ini telah berlangsung dengan baik dan sesuai dengan target. Indikator keberhasilan kegiatan ini adalah terbitnya buku yang berisi hasil karya peserta kegiatan literasi gender sebagai luaran. Hasil
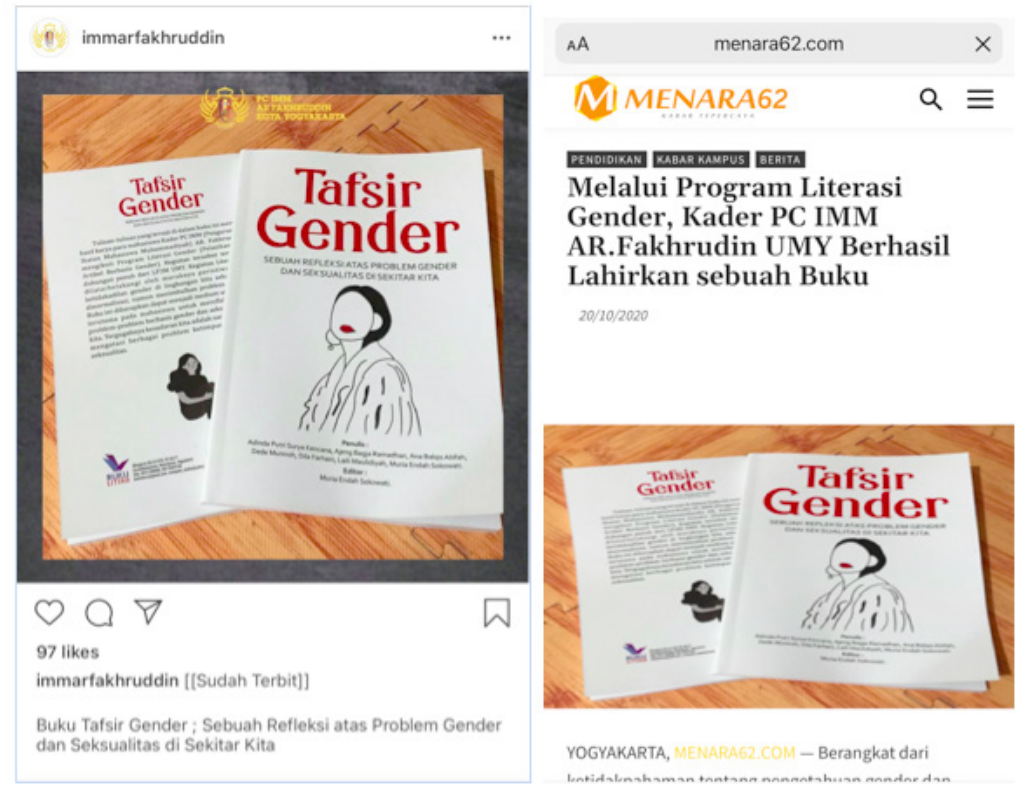

Gambar 6. Publikasi Buku Tafsir Gender di Akun Instagram PC IMM AR Fakhruddin, bisa di akses di https://www.instagram.com/p/CGOZoPWgrx2/?igshid=225t4imz7vyo, dan publikasi penerbitan buku Tafsir Gender di menara62.com, dapat diakses di https://menara62.com/melalui-programliterasi-gender-kader-pc-imm-ar-fakhrudin-umy-berhasil-lahirkan-sebuah-buku/ 
tulisan peserta menggambarkan pemahaman mereka tentang konsep dan problem gender dan seksualitas. Tulisan peserta diharapkan menjadi sarana edukasi bagi para pembaca, sehingga edukasi gender dan seksualitas dapat menyebar ke lingkaran yang lebih luas.

Pendemi Covid-19 yang berpengaruh pada terlaksananya kegiatan ini ternyata tidak banyak menghambat para peserta untuk berpartisipasi pada proyek penulisan buku. Memang ada sedikit kendala dalam hal koordinasi, namun hal tersebut dapat diatasi dan penerbitan buku tetap dapat dilakukan tepat waktu.

Kegiatan ini sangat bagus dilakukan dengan menjangkau kalangan-kalangan lainnya, mulai dari anak-anak, remaja, ibu-ibu, bapak-bapak, guru, dan sebagainya. Untuk itu, pelaksanaan kegiatan sejenis sangat penting bagi targettarget lainnya yang tentu saja dengan strategi dan materi yang disesuaikan dengan kebutuhan dan karakteristik target peserta.

\section{PERSANTUNAN}

Ucapan terima kasih dan apresiasi kami berikan kepada LP3M UMY atas dukungan penuh baik material maupun nonmaterial hingga terlaksananya kegiatan ini. Selain itu ucapan terima kasih juga kami berikan pada PC IMM AR. Fakhruddin atas kerjasamanya yang sangat baik selama berlangsungnya kegiatan ini.

\section{REFERENSI}

Ashuro, A. Siregar, I. Rochani, S. (2010). Sosialisasi Gender oleh Orang Tua dan Prasangka Gender pada Remaja. Jurnal Psikologi, 3(2),141-147.

Bahransyaf, D. (2016). Pemahaman Masyarakat tentang Kekerasan Seksual pada Anak di Kupang. Sosio Konsepsia, 5(3), 154-168.

Boediarsih, Shaluhiyah, Syamsulhuda. (2016). Persepsi Remaja tentang Peran Gender dan Gender Seksualitas di Kota Semarang. Jurnal Promosi Kesehatan Indonesia. 11(1), 28-37.

Cole, N. L. (2015) The Most Important Words in Emma Watson's Speech Were Abaut Masculinity: He for She Challenges Men and Boys to Embrace Feminism. Tidak Dipublikasikan.

Hasan, AM. (2017, 21 April). Ketimpangan Gender dan Kendali Perempuan Milenial. Tirto.id. Diakses dari https://tirto.id/ketimpangan-gender-dan-kendali-perempuan-milenial-cnb5

Kirsch, S. J. (2010). Media and Youth: A Developmental Perspective, UK: Willey-Blackwell Publishing.

Kusuma, R. S. (2017). Komunikasi Antar Pribadi sebagai Solusi Konflik pada Hubungan Remaja dan Orang Tua di SMK Batik 2 Surakarta, Warta LPM, 20(1), 49-54.

Purwahida, R. dan Huda, M. (2010). Sosialisasi Pembelajaran Sastra Berperspektif Jender bagi Guru SMA/SMK Se-Surakarta. Warta LPM, 13(1), 77 - 88.

Puspita, D. R., Wahyuningrat, Dharma, P. dan Isna, A. (2019). Pengembangan Kapasitas Penyuluhan berbasis Masyarakat Berperspektif Gender dalam Meningkatkan Ketahanan Keluarga di Kecamatan Sumbang, Kabupaten Banyumas. Dinamika Journal, 1(4), 24-36.

Rofi'ah, S. dan Jasminto. (2018). Pemberdayaan Anak Korban Kekerasan Seksual berbasis Gender melalui Self Efikasi di Jombang. Engagement, 2(2), 249-259.

Sujadmi, Febriani, L., Herdiyanti. (2018). Upaya Pencegahan Sexual Violence pada Remaja Sekolah di Merawang Kabupaten Bangka. Society, 6(2), 2597-4874.

Warmiyati, M. T., Wijayanti, S. H., Darmoyo, S. (2018). Pemahaman tentang Sosialisasi Gender pada Siswa SMA di Jakarta. Jurnal Muara Ilmu Sosial, Humaniora, Dan Seni, 2(1), 411-419.

Witriani dan Kusuma, BMA. (2019). Mapping Isu Jurnal Berbasis Pengarusutamaan Gender dan HAM pada Perguruan Tinggi di Indonesia. Musawa, 18(1), 45-59. 